\title{
Article
}

\section{Electronic repeat dispensing}

Davies, Janice Anne

Available at http://clok.uclan.ac.uk/33754/

Davies, Janice Anne (2020) Electronic repeat dispensing. Journal of Prescribing Practice, 2 (6). p. 278. ISSN 2631-8385

It is advisable to refer to the publisher's version if you intend to cite from the work.

10.12968/jprp.2020.2.6.278

For more information about UCLan's research in this area go to

http://www.uclan.ac.uk/researchgroups/ and search for < name of research Group>.

For information about Research generally at UCLan please go to http://www.uclan.ac.uk/research/

All outputs in CLoK are protected by Intellectual Property Rights law, including Copyright law. Copyright, IPR and Moral Rights for the works on this site are retained by the individual authors and/or other copyright owners. Terms and conditions for use of this material are defined in the policies page.

\section{CLoK}

Central Lancashire online Knowledge www.clok.uclan.ac.uk

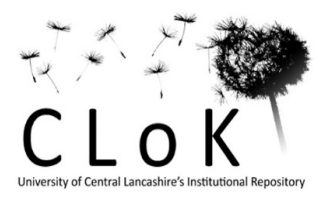


Electronic repeat dispensing (eRD) is an integral part of the electronic prescription service EPS, which offers many extra benefits over paper repeat dispensing and repeat prescribing. Electronic repeat dispensing is a recommended strategy for managing medicines during the Covid-19 pandemic.

- two-thirds of prescriptions issued in primary care are repeat prescriptions. These repeat prescriptions account for nearly $80 \%$ of NHS medicine costs for primary care

- 410 million repeat prescriptions are generated every year - equivalent to an average of more than 375 per GP per week

- it's estimated that up to 330 million, or $80 \%$, of all repeat prescriptions could eventually be replaced with eRD

- this could save 2.7 million hours of GP and practice time

Ref https://digital.nhs.uk/services/electronic-prescription-service/electronic-repeatdispensing-for-prescribers\#benefits-of-using-electronic-repeat-dispensing-erd- last edited 3.6.19

It is always important to prescribe the correct quantity of medication to reduce waste and prevent confusion for the patient, however this is even more important when using eRD because your repeatable prescription could be repeated 13 times ie for one whole year.

Inhalers are available in a range of pack sizes. The dose and quantity required for one month varies according the specific inhaler. Complete this table to ensure that you prescribe the correct quantity on eRD for inhalers: 


\begin{tabular}{|c|c|c|c|c|}
\hline $\begin{array}{l}\text { NUMBER } \\
\text { OF DOSES } \\
\text { PER } \\
\text { INHALER }\end{array}$ & $\begin{array}{c}\text { NUMBER OF DOSES } \\
\text { PER DAY }\end{array}$ & $\begin{array}{c}\text { NUMBER OF } \\
\text { DOSES PER } \\
\text { MONTH }\end{array}$ & $\begin{array}{c}\text { HOW MANY } \\
\text { DAYS WILL THIS } \\
\text { LAST? }\end{array}$ & \begin{tabular}{|} 
APPROXIMATELY \\
HOW MANY \\
WEEKS OR \\
MONTHS WILL \\
THIS LAST?
\end{tabular} \\
\hline 200 & One puff twice a day & 56 & 100 days & 3 months \\
\hline 200 & $\begin{array}{c}\text { Two puffs twice a } \\
\text { day }\end{array}$ & 112 & 50 days & 7 weeks \\
\hline 200 & $\begin{array}{c}\text { Two puffs three } \\
\text { times a day }\end{array}$ & 168 & 33 Days & 4 - 5 weeks \\
\hline 200 & $\begin{array}{c}\text { Two puffs four times } \\
\text { a day }\end{array}$ & 224 & 25 days & 3 - 4 weeks \\
\hline 120 & One puff twice a day & 56 & 60 days & 2 months \\
\hline 120 & $\begin{array}{c}\text { Two puffs twice a } \\
\text { day }\end{array}$ & 112 & 30 days & 1 month \\
\hline 60 & One puff twice a day & 56 & 30 days & 1 month \\
\hline
\end{tabular}

